\title{
An Analysis of Government Interventions in Addressing Market Failures Caused by Non- Excludable and Non-Rivalrous Public Goods Based on COVID-19 Vaccination Cases
}

\author{
Wenqing Chen* \\ University of Birmingham, Birmingham B15 2TT, United Kingdom \\ *Corresponding author: Wenqing Chen, $419322781 @ q q . c o m$
}

\begin{abstract}
The non-excludable and non-rivalrous characteristics of public goods distinguish them from private goods. The existence of these two characteristics leads to the "free rider problem" and the variation problem, making the market supply less than the actual demand, thus causing market failure. The government should therefore intervene against this impact. At the beginning of 2020, the global outbreak of the novel COVID-19 brought significant harm to various countries, races, and groups of people. In the second half of 2020, several companies developed vaccines, which are able to fundamentally block the transmission of the virus. However, as vaccines have been reducing the severity of the epidemic in certain regions, the situation somewhat reflects non-excludability and non-rivalry, in which before officially being listed in vaccination programs, the society may have the thought of "vaccination would reduce the risk of transmission; thus, I can enjoy the reduced risk of everyone being vaccinated without paying for it." For this reason, most countries have been purchasing vaccines for the public through government appropriations to solve the free-rider problem. It can be said that in the face of market failure caused by public goods, the government should carry out timely intervention measures, including taxation and government appropriation, to avoid negative impacts from the characteristics of public goods.
\end{abstract}

Keywords: Public goods; Free rider; Non-excludable; Non-rival

Publication date: October 2021; Online publication: October 29, 2021

\section{Introduction}

In 2020, the worldwide outbreak of COVID-19 has been arguably the most serious health crisis faced by mankind since the Spanish influenza pandemic of the last century. The coronavirus (COVID-19), which is characterized as a pandemic by the World Health Organization (WHO), has been attacking societies at their core ${ }^{[1]}$. This pandemic has greatly affected every country and person. It has had a tremendous impact on the global politics, economic, culture, social, and others. To this end, all countries have made great efforts to deal with the outbreak, thus containing the spread of the epidemic to a certain extent. In the second half of 2020, a number of pharmaceutical companies have developed effective vaccines against COVID-19. After vaccination, the recipients would be able to produce antibodies, thus curtailing the spread of the epidemic at the source. It is regarded as an effective solution for various countries to solve the epidemic. However, none of the vaccines are $100 \%$ effective. So far, vaccines appear safe from clinical trials but nothing, including paracetamol, is $100 \%$ safe $^{[2]}$. In order to stop or slow the spread of the virus from person to person, everyone must be vaccinated. Since the virus spreads from person to person and vaccines are used to develop resistance to the virus, vaccines are reflected as non-excludable and non-rivalrous. Due to the existence of vaccination to reduce the risk of the spread of the virus, no one can stop the exclusion from 
this profit; the lower risk of the spread and the reduced risk would not produce rivalry so as to make vaccines as public goods.

The prices of COVID-19 vaccines would not be announced until the Chinese government is ready to roll out a policy of universal vaccination, and debate is already underway in China over whether citizens are able to be vaccinated for free. The unmistakable sound is that "if everyone but me gets vaccinated, the virus would not spread among us, and I can benefit from the reduced risk of transmission without paying for it." This is a typical free-rider problem caused by the characteristics of public goods.

\section{Main content}

Public goods and private goods are a relative concept because some goods are produced mainly for public utilities services. The fundamental difference between the two is that private goods have two characteristics which are excludable and rivalrous ${ }^{[3]}$.

Non-excludable refers to when a person pays for a type of public good, the use of this good by others cannot be avoided. For example, the irradiation of light off the coast of the lighthouse to the sea; when a boat passes that area, it can enjoy the service from the beacon lights, no one can stop other ships from receiving the light. The problem of this commodity is that if a shipping company is concerned about the process of their ships sailing on sea without light, they would invest to build and run a lighthouse, but boats from other companies can also acquire the light from the lighthouse that was built by the first company, although they do not have to invest any money for the construction of the lighthouse.

When someone drinks a cup of coffee, that cup of coffee cannot be drunk by others so there is rivalry in the situation of who can consume that cup of coffee and the coffee is rivalrous. Non-rivalry is when a person's consumption of this kind of public goods does not affect the consumption of others; a man walking through the bridge does not hinder others from crossing the bridge; a person watching certain types of programs on television does not have any effect on others.

To sum up, the core differences between public goods and private goods lie in whether the goods have non-rivalrous and non-excludable characteristics. Some goods have the characteristics of public goods and also those of private goods; thus, they are known as quasi-public goods, or down to a non-excludable and rival "item" pond or excludable and non-rival "club goods." In reality, under special circumstances, a lot of public goods which are non-rival and non-excludable in a limited degree will gradually reflect its excludability or rivalry. In actual government management, a country tends to have all kinds of cases where although some goods are public goods, due to the large population, they appear excludable or rivalrous; on the other hand, some private goods reflect the nature of public goods in some cases, requiring the managers of public utilities to look at each case dialectically.

The reason that public goods are made is to serve the public. In regard to that, the public will naturally think that public goods are beneficial to the society. However, when public goods enter the market, they would harm the entire market because they are non-excludable and non-rivalrous, leading to the free-rider problem where everyone wants to take advantage. For example, a scenario where a bridge is built beside a person's door, others cannot stop that person from crossing the bridge, so why should that person pay for the bridge? Some people may initiatively pay for public goods in view of their moral values, but the money paid for public goods is less compared to the occurrence of the free-rider phenomenon. The existence of free-rider and the paying of goods by consumers play roles in the market demand. When free riding is impossible, the payment for goods would be the actual demand. This leads to the demand of the market being lower than the actual demand. The market is based on what it considers as the demand production. In other words, the free-rider problem leads to insufficient supply of relevant goods, thus causing market 
failure.

Economic efficiency is a situation where resources (raw material, labor, land, and capital) are allocated and used in the most productive manner possible ${ }^{[4]}$. The failure of the market leads to the inability of various productive sectors to allocate resources efficiently. Therefore, the government must intervene when the market fails and ensure that the market returns to an efficient situation as soon as possible.

In regard to market failure caused by insufficient market supply of public goods, the government can implement solutions such as taxation, government paying for the public, determining property rights, binding public goods with private goods, and contract negotiation ${ }^{[5]}$. The reason for market failure is that the non-excludability and non-rivalry of public goods lead to the free-riding problem, which can be solved by collecting funds, determining property rights, and coordinating. Suppose in a case of a construction of a bridge, as a public good in the service of the city, the use of the bridge by people who have not paid for it cannot be prevented. In consulting the public's will before the construction, some people would decide not to express their will about the bridge because they do not want pay for it. The actual demand should have been reflected by a large sum of money to build a huge bridge, but because some people conceal their will about the bridge, only a small bridge can be built as the funds raised are minimal. In order to solve the problem where people hide their actual desires for the bridge to avoid funding, the government should make it clear that the people do not need to pay for the bridge when soliciting opinions (although the money may still come from the citizens' taxes) so that people can express their actual desires. From the perspective of economics, the contractor would receive the full amount of funds paid by the government, making the demand judged by the market closer to the actual demand, thus effectively improving the market failure.

Other than the funding by the government to avoid the free-rider problem, through certain property rights, binding of public goods and private goods, as well as contract negotiation, the government can encourage individuals to solve the free rider problem through administrative means. Although the effect from government's funding for public goods is more obvious, but to a certain extent, these would also alleviate the phenomenon of market failure. Contract negotiation is a very good way of solving the "lighthouse effect" in the aforementioned case of constructing a lighthouse. Perhaps, ship captains are selfemployed, thus having insufficient funds to build a lighthouse and the communication between the captains rarely occur. In such a case, everyone has a demand for a lighthouse, and they are concerned about their lives so they are willing to invest in a lighthouse, but it is difficult for them to raise funds individually. Eventually, the market does not know of this demand because the contractors do not receive funds for the construction. This leads to market failure as the market demand is less than the actual demand and the supply of public goods is insufficient in this situation. Therefore, the government needs to act as a negotiator to ensure the beneficiaries of public goods negotiate with each other and invest for their benefits while encouraging them to raise money together in order to reduce the gap between the market demand and the actual demand, thus improving the market failure.

In general, the government has the means of dealing with market failure caused by the nature of public goods by levying taxes and purchasing public goods on behalf of the beneficiaries via determining property rights, binding public goods with private goods, negotiating contracts, etc. The government should implement the most effective way to avoid market failures caused by public goods in accordance to the different categories of public goods and actual cases.

As mentioned, vaccination has made it almost impossible for the recipients to be infected with the virus, thus reducing the transmission among the population and the risk of local spread. Since vaccines reflect non-excludability and non-rivalry; that is to say, the resulting reduction in the risk creates a situation where the unvaccinated cannot be excluded from the benefit of risk reduction. In regard to that, people would tend 
to "free-ride" to enjoy the reduction of risk without paying for their vaccinations. The government can improve the market failure caused by public goods through taxation or by paying for those public goods. In this case, most countries have chosen to purchase vaccines via being funded by the government so that the public would be able to be vaccinated for free, thus reducing the risk of infection among people.

\section{Conclusion}

How will the economics research community manage its scarce resources ${ }^{[6]}$ ? In a normal market, supply and demand divert resources to the sectors where they can be best used. However, in view of the nonexcludability and non-rivalry of public goods which lead to problems such as "free-riding" and market failure as the market demand is less than the actual demand, the government can intervene through capital taxation, funding, property determination, binding public goods with private goods, as well as contract negotiation. In the case of vaccine distribution, the actual situation has shown the problems that vaccines, a public good, can bring to the market while alleviating the global pandemic. For this reason, many countries have chosen to provide free vaccines at the government's expense, thus improving the market failure caused by vaccines and improving the epidemic in a practical sense. It can be said that in the face of various challenges and crises, the government should judge based on the origin, impact, and solutions of the problems involved in the actual cases they encounter, bravely assume their corresponding responsibilities, intervene in the market, as well as ensure its return to a normal and efficient state.

\section{Disclosure statement}

The author declares that there is no conflict of interest.

\section{References}

[1] DISD, 2021, Everyone Included: Social Impact Of COVID-19 | DISD. https://www.un.org/development/desa/dspd/everyone-included-covid-19.html (accessed January 8, 2021).

[2] Gallagher J, 2021, Covid Vaccine: First 'Milestone' Vaccine Offers 90\% Protection. BBC News. https://www.bbc.com/news/health-54873105 (accessed January 10, 2021).

[3] Watt P, 2020, Public Goods. University of Birmingham.

[4] Greater London Authority, 2008, The Rationale for Public Sector Intervention in the Economy II. https://www.london.gov.uk/sites/default/files/gla_migrate_files_destination/rationale-invention.pdf (accessed January 11, 2021).

[5] Cowen T, 2018, Public Goods. Econlib. http://www.econlib.org/library/Enc/PublicGoods.html

[6] Mankiw N, 2014, Principles Of Economics 7th Edition, South-Western College Pub, 3. 